Pak. j. sci. ind. res. Ser. B: biol. sci. 2021 64B(1) 18-24

\title{
The Development of Mucosal Immunization as an Alternative Approach for Production of Antisera Against Saw Scale Viper from Sindh
}

\author{
Zameer Ahmed $^{* a, b}$, Sambreen Zameer ${ }^{a, b}$, Shaheen Sharafat ${ }^{a}$ and Muhammad Rafiq Khanani ${ }^{a}$ \\ ${ }^{a}$ Department of Laboratory Animal Sciences, Ojha Campus Dow, University of Health Sciences Karachi, Pakistan, \\ ${ }^{\mathrm{b}}$ Dow Medical College, Dow University of Health Sciences, Karachi
}

(received August 22, 2019; revised November 24, 2019; accepted November 27, 2019)

\begin{abstract}
The reported cases of snake bite are 5.4 million per year, making the serious envenoming issue so, that WHO categorises cases of snake bite in neglected tropical diseases. Anti snake venom is produced by intramuscular injection of crude venom with different formulation of adjuvants to equine animals, but these intramuscular injections have several serious health impact in equine. Snake species categorised according to geographical locations, and there is a different composition of the snake venom at different locations. So, this research had been designed and evaluated new oral adjuvant formulation for viper family of Sindh, Pakistan. This is a animal immune based analysis consisting two Saw scale viper from Thar and costal area of Sindh because both have different habitat and morphological appearance. The venom toxin protein, combined with a mineral oil adjuvant for oral immunization. The adjuvant with venom via oral route produced of specific $\mathrm{Ig}_{\mathrm{g}}$ and horse give maximum response with three doses of venom. The antibody titer was measured by ELISA showed significant results in both groups. For confirmation of specific antibodies isolated from horse serum, serum neutalization assay and immunodiffusion test were carried out. The snake venom with oral adjuvant immunization, is safe, efficient and time saving for production of equine Immunoglobulins IgG.
\end{abstract}

Keywords: oral immunization, venoms, saw-scale viper, immunoglobulins ( $\left.\mathrm{I}_{\mathrm{g} G}\right)$

\section{Introduction}

The snake bite cases from Thar parker district of Pakistan are very distinct from other snake bite cases because of difference in snake variety. The saw-scaled vipers are the primary causes of snakebite morbidity and mortality in the desert area of Sindh, Pakistan. Similar circumtances are reported from African, Middle east countries, which creating problem in handling of snake bite cases Pouyani et al. (2016).

The worldwide estimated snake bite cases are 5.4 million out of which 2.5 million envenomation and 125,000 deaths per year. It is estimated that there are more than $1,000,000$ snake bites in India alone leading to between 45000 to 50000 deaths per year Menno et al. (2017). South Asia has the highest rate of snake bite cases. India has highest mortality index; Pakistan has no accurate available data, but approximately 40,000 reported cases of snakebites and 8000 fatal cases per year are recorded by a literature search. In SriLanka, approximately 33,000 cases per annum, and in Nepal 1,000 death per year

*Author for correspondence; E-mail:

ahmed_dr2003@yahoo.com recorded. The fatality rate is more or less same in the Asian region that is about 20\% Parveen et al. (2017)

This serious envenoming problem and increase numbers of deaths has led WHO to recognise it as one of the neglected tropical diseases, chiefly accepted as an occupational hazard and a disease of poverty. So, the investigator started to design and achieve a better consideration of the compositional difference of venoms and assist the production of affordable, effective antivenoms against the majority of venomous snakes to solve the problem. The most effective treatment for snake envenomation is the administration of particular antivenom scince many decades, which remains scarce in many parts of the world. Ratanabanangkoon et al. (2016)

Until launching a pharmaceutical product with complete identification, purity, protection and efficacy profiles anti-snake venoms development must follow the requirements of Good Manufacturing Practices (GMPs), including animal ethics. The identity of anti-snake venoms is determined by the equine animal species used as a source of immunoglobulin and the snake venoms source used as immunogens, León et al. (2018) 
Worldwide, many immunization methods have been discovered, such as recombinant toxins, synthetic peptides, or just the isolalion of antigenic epitopes by different molecular digestion techniques, but in case of snake venom, the venomous animals essential to keep in captivity antivenom production open the era of new immunization approaches is considered relatively possible and adapted by manufacturers without introducing significant changes. Furthermore, since antivenoms gained by using novel immunization strategies have no differences as obtain from traditional antivenoms. The regulating bodies' endorsement processes should not restrain their product in the market. However, with these benefits, there is batch-to-batch difference is still expected, as a importance of immune response of immunized animals, Bermúdez et al. (2018)

In Pakistan, Echis carinatus (saw-scaled viper) are commonly found in desert areas, especially in agriculture land, calltle shades (Ther, Cholistan, and Makran in Baluchistan). It is a flat body with short tapered tail measuring about 0.4 to. 6 meters long that travels rapidly in the opposite direction of the air flow. Echis carinatus have different variations of colours such as gray, olive or brown tone, back and some times both sides have different colours, with small white spots, (Parveen et al., 2017; Odedara, 2017).

Saw-scale viper venom act as potent procoagulant toxins, which lead to venom-induced consumption coagulopathy (VICC) is the significant clinical manifestations in humans. Venom activates the clotting pathway by procoagulant toxins, resulting in clotting factor defect. The procoagulant toxin type varies between snakes species and can activate factor $\mathrm{X}$ and $\mathrm{V}$, prothrombin activator or consume fibrinogen. (Rogalski et al., 2017; Berling and Isbiter, 2015).

Therefore, the present study designed to establish a new strategy oral immunization in order to enhance the titer of antibodies against the venom of two saw-scale viper found in Sindh, Pakistan. As adjuvants are used for many decades for enhancement of immunogen activity, and in animals these adjuvants are used for production of hyperimmune sera, Valverde et al. (2017). Oil based vaccine are commonly practiced for veterinary controllable diseases which is designed for single dose for life long immune response against diseases studied by Park et al. (2016) The researchers have been started working out the oral immunization technique, especially for the cure of Mycobacterium tuberculosis. So, we also design the mucosal immunization technique for production of specific anti snake venom against local viper family of Sindh, (Chambers et al., 2017; BeltránBeck et al., 2014).

\section{Materials and Methods}

Ethical considerations. All experimental horses were kept in the departmental of laboratory animal sciences Ojha campus, Dow University of Health sciences under the supervision of equine veterinarians. Ethical approval letter No (IRB-685/DUHS approval/2016/184) for the present study has been taken from Institutional Board Review Committee, Dow University of Health Sciences, Karachi.

Venom collection. Saw-scale viper have different groups which also have a different morphology and habitat. We collected venomous saw scale vipers from Ketti Bander, Kachall Border, Jhang, Qader Loo, Jatti, Shah Latife, Chill Mehar, (coastal areas) and Therparker district of Sindh (Fig. 1-2). The costal area viper are still not categories as species or sub species of sawscale viper its need another detail study but these snake have their on habitat. All snakes were kept in the snake house at the Laboratory Animal Science Department, DUHS.

Venom was collected mennually with standard protocol provided by WHO. Then venom was centrifuged at 2500 RPM for $30 \mathrm{~min}$. for cleaning the sample, freeze dried and stored at $-20{ }^{\circ} \mathrm{C}$ till used.

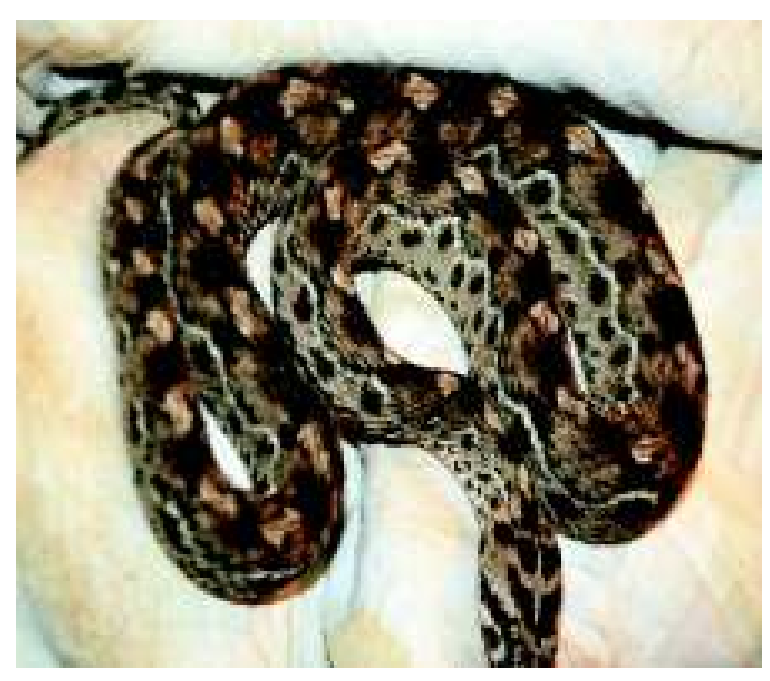

Fig. 1. Saw-scale viper of costal area (Sindh). 


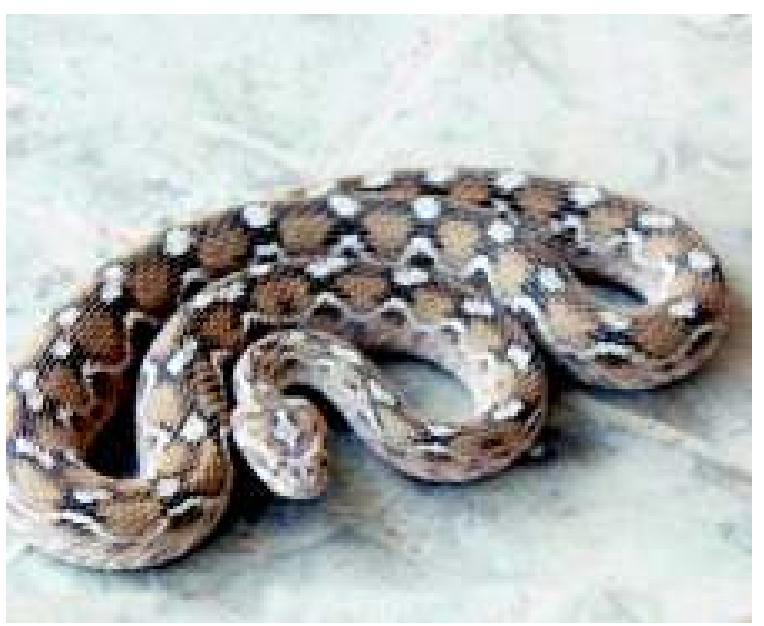

Fig. 2. Saw-scale viper of Tharparker (Sindh).

Animal study plan. In breed line NIMRI mice strain weighting from $20-30 \mathrm{~g}$ were selected for venom dose calculation (lethality testing and neutralization Assays), and Local horses age ranges from 3 to 8 years, weight 200-300 Kg was included in this study for immunization protocol, purchase from local farmers after certification by a veterinarian.

All experimental groups (large and small animals) were kept in Laboratory Animal Science Department, DUHS under supervision of veterinary consultant.

Venom protein estimation. The venom protein was estimated by standard Bradford method. The basic principle of this assay is the conversion of Coomassie Brilliant Blue G-250 dye into different colours that is neutral (green), anionic (blue) and cationic (red). The existence of protein in the dye forms a strong, noncovalent complex with the protein's carboxyl group by Van der Waals forces and amino group through electrostatic interactions, which is measured by the use of a calorimetric absorbance reading. Cheng et al. (2016) (Bradford kit provided by Thermo Scientific ${ }^{\mathrm{TM}}$ )

- Tharparker saw-scale viper protein calculated as $90 \mu \mathrm{g} / \mu \mathrm{L}$ of venom.
- Coastal saw-scale viper protein calculated as $120 \mu \mathrm{g} / \mu \mathrm{L}$ of venom.

The venom protein was calculated for $\mathrm{LD}^{100}$ in mice. Hosseini et al. (2017)

Toxicological studies. Toxicological study was done in two groups of NIMRI mice. Each dilution tested on five mice with one control. One group for coastal sawscale viper and $2^{\text {nd }}$ group for Tharparker district sawscale viper (SSV) which are shown in Table 1.

The venom was serially diluted by $1: 9$ ratio and from each dilution injected to five mice by intraperitoneal route. Dead or alive mice were observed and recorded from 24 to $48 \mathrm{~h}$, respectively. WHO guidelines (2010).

Animal husbandry conditions. Good animal handeling, high nutritional diet, water and biological stress free conditions were provided. Daily veterinary examination and treatment have been provided as per requirement.

Preparations of adjuvants. The small animals NIMRI mice was used to find out the ideal concentration of (adjuvants with venom protein combinations) to develop an oral adjuvant formulation by (v/v) Tween ${ }^{20}$ Tween $^{80}$, Mineral oil, PBS and saw-scale snake venom. These were mixed with a vortex mixture till dense creamy white or light brown colour (emulsion) appeared, Shah et al. (2015). The orally by $0.5 \mathrm{~mL}$ from each ratio given feeding tube in five mice for tolaratability, shown in Table 2.

\section{Protocol for monovalent immunization of horses.}

Ten horses were allotted for research trial as given a unique number, name and after passes the quarantine time, horses distributed in two groups each group, have five in for protocol 1 and protocol No. 2 (Thar SSV and costal area SSV respectively). Prior to immunization of horses, serum was collected from all animals and stored as negative controls, shown in Fig. 1.

Isolation and testing of horse $\mathbf{I}_{\mathbf{g}} \mathbf{G}$. We use caprylic acid for precipitation technique for commercial production of anti-snake venom. Quantification of horse

Table 1. Toxicological studies into two groups.

\begin{tabular}{llllll}
\hline \hline Snake venom & Dilution 1 & Dilution 2 & Dilution 3 & Route of injection & Control \\
& $0.5 \mathrm{~mL} / \mathrm{mice}$ & $0.5 \mathrm{~mL} / \mathrm{mice}$ & $0.5 \mathrm{~mL} / \mathrm{mice}$ & $0.5 \mathrm{~mL} / \mathrm{mice}$ & \\
\hline Costal SSV & 0.5 & 0.5 & 0.5 & Intraperitoneal & 0.1 \\
Thar SSV & 0.5 & 0.5 & 0.5 & Intraperitoneal & 0.1 \\
\hline \hline
\end{tabular}


Table 2. Preparation of venom protein formulation

\begin{tabular}{|c|c|c|c|c|c|}
\hline $\begin{array}{l}\text { Snake Venom } \\
\text { fixed volume }\end{array}$ & $\begin{array}{l}\text { Adjuvant ratiol } \\
10 \%(\mathrm{v} / \mathrm{v}) 0.5 \\
\mathrm{~mL} / \mathrm{mice}\end{array}$ & $\begin{array}{l}\text { Adjuvant ratio } 2 \\
20 \%(\mathrm{v} / \mathrm{v}) 0.5 \\
\mathrm{~mL} / \mathrm{mice}\end{array}$ & $\begin{array}{l}\text { Adjuvant ratio } 3 \\
30 \%(\mathrm{v} / \mathrm{v}) 0.5 \\
\mathrm{~mL} / \mathrm{mice}\end{array}$ & Route of injection & Control \\
\hline Costal SSV & 05 & 05 & 05 & Orally & 01 \\
\hline Thar SSV & 05 & 05 & 05 & Orally & 01 \\
\hline
\end{tabular}

$\mathrm{Ig}_{\mathrm{g}} \mathrm{G}$ against snake venoms in the different groups of horses sera was analyzed by modifying enzyme link immuno sorbent assay (ELISA), the absorbance values read at $492 \mathrm{~nm}$ with the help of ELISA reader, and the results were recorded.

The specific immunoglobulin against snake venoms, neutralised by agar gel immunodiffusion test was performed using an Ouchterlony double immunodiffusion technique which is shown in Fig. 3.

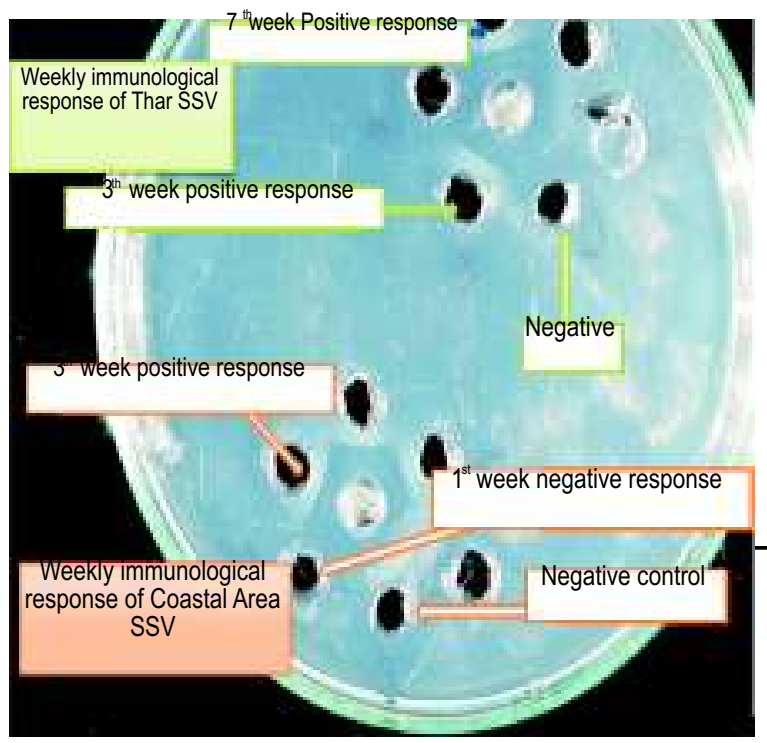

Fig. 3. Immunodiffusion results of Thar and coastal area saw-scale viper.
Statistical analysis. All data were calculated and analysed by SPSS version 16 with paired sample T test for standard deviation.

\section{Results and Discussion}

$\mathbf{L D}^{\mathbf{1 0 0}}$ for snake venom. In mouse strains, the mortality of saw-scale viper snake venom was checked. It was found that intraperitoneal route was ideal in NIMRI mice for calculation of $\mathrm{LD}^{100}$. The result of $\mathrm{LD}^{100}$ of costal area SSV venom was $480 \mu \mathrm{g} / 25 \mathrm{~g}$ body weight of mice and for Thar SSV venom was $360 \mu \mathrm{g} / 25 \mathrm{~g}$.

Table 4 and Fig. 4 shows the antibodies (IgG) titer measured by ELISA. The result was statistically

Table 4. Comparison of antivenom of Thar SSV with costal area SSV produced by oral adjuvant measured by ELISA

\begin{tabular}{lll}
\hline \hline Weeks & $\begin{array}{l}\text { Antivenom of } \\
\text { Thar SSV } \\
(\mu \mathrm{g} / \mu \mathrm{L} \text { of } \mathrm{IgG})\end{array}$ & $\begin{array}{l}\text { Antivenom of } \\
\text { costal area SSV } \\
(\mu \mathrm{g} / \mu \mathrm{L} \text { of } \mathrm{IgG})\end{array}$ \\
\hline $\begin{array}{l}\text { 0 week } \\
\text { (Pre-venom) bleed }\end{array}$ & 0.0 & 0.0 \\
$\begin{array}{l}1 \text { week } \\
\text { after the first dose }\end{array}$ & 0.6 & 0.8 \\
$\begin{array}{l}3 \text { weeks after } \\
\text { Second dose } \\
7 \text { weeks after }\end{array}$ & 1.7 & 1.9 \\
$3^{\text {rd } \text { dose }}$ & 2.9 & 3.1 \\
\hline
\end{tabular}

*Elisa (absorbance at $492 \mathrm{~nm}$ ); Statistically significant differences between oral adjuvant $(\mathrm{P}<0.058)$.

Table 3. Protocol for monovalent immunization of Horses

\begin{tabular}{|c|c|c|c|c|}
\hline $\begin{array}{l}\text { Immunization } \\
\text { week }\end{array}$ & $\begin{array}{l}\text { Adjuvant } \\
\text { composition }\end{array}$ & $\begin{array}{l}\text { Protocol } 1 \\
\text { Thar SSV (venom) }\end{array}$ & $\begin{array}{l}\text { Protocol } 2 \\
\text { costal area SSV } \\
\text { (venom) }\end{array}$ & Route \\
\hline 1 & $\begin{array}{l}\text { Tween }^{20} \& \text { Tween }^{80} \\
\text { Mineral oil, PBS }\end{array}$ & $500 \mu \mathrm{L}$ & $500 \mu \mathrm{L}$ & Orally \\
\hline 3 & $\begin{array}{l}\text { Tween }^{20} \& \text { Tween }^{80} \\
\text { Mineral oils, PBS }\end{array}$ & $250 \mu \mathrm{L}$ & $250 \mu \mathrm{L}$ & Orally \\
\hline 7 & $\begin{array}{l}\text { Tween }^{20} \& \text { Tween }^{80} \\
\text { Mineral oils, PBS }\end{array}$ & $200 \mu \mathrm{L}$ & $200 \mu \mathrm{L}$ & Orally \\
\hline
\end{tabular}


Table 5. Serum neutralization assay of Thar SSV venom by in vivo studies

\begin{tabular}{|c|c|c|c|c|c|c|c|}
\hline Weeks & $\begin{array}{l}\text { Fixed amount } \\
\text { of } \mathrm{LD}^{100} \text { venom } \\
(\mu \mathrm{L})\end{array}$ & $\begin{array}{l}\text { IgG Antibodies } \\
(\mu L)\end{array}$ & $\begin{array}{l}\text { Vivo } \\
\text { studies }\end{array}$ & $\begin{array}{l}\text { Live } \\
\text { mice } \\
\text { (Mice) }\end{array}$ & $\begin{array}{l}\text { Dead } \\
\text { mice }\end{array}$ & $\begin{array}{l}\text { Control } \\
\text { mice one } \\
\text { for each group }\end{array}$ & Remarks \\
\hline $\begin{array}{l}0 \text { Week } \\
\text { (Prevenom) }\end{array}$ & 40 & 150 & 5 & ---- & 5 & Alive & \\
\hline After $1^{\text {st }}$ week & 40 & 150 & 5 & ---- & 5 & Alive & \\
\hline $3^{\text {rd }}$ Week & 40 & 150 & 5 & 4 & 1 & Alive & $80 \%$ \\
\hline $7^{\text {th }}$ Week & 40 & 150 & 5 & 5 & 0 & Alive & $100 \%$ \\
\hline
\end{tabular}

Table 6. Serum neutralization assay of costal area SSV venom by in vivo studies

\begin{tabular}{|c|c|c|c|c|c|c|c|}
\hline Weeks & $\begin{array}{l}\text { Fixed amount } \\
\text { of } \mathrm{LD}^{100} \text { venom } \\
(\mu \mathrm{L})\end{array}$ & $\begin{array}{l}\mathrm{Ig}_{\mathrm{g}} \mathrm{G} \\
\text { Antibodies } \\
(\mu \mathrm{L})\end{array}$ & $\begin{array}{l}\text { Vivo } \\
\text { studies } \\
\text { (Mice) }\end{array}$ & $\begin{array}{l}\text { Live } \\
\text { mice }\end{array}$ & $\begin{array}{l}\text { Dead } \\
\text { mice }\end{array}$ & $\begin{array}{l}\text { Control } \\
\text { mice one } \\
\text { for each group }\end{array}$ & Remarks \\
\hline 0 Week (Prevenom) & 40 & 150 & 5 & ---- & 5 & Alive & \\
\hline After $1^{\text {st }}$ week & 40 & 150 & 5 & ---- & 5 & Alive & \\
\hline $3^{\text {rd }}$ Week & 40 & 150 & 5 & 4 & 1 & Alive & $80 \%$ \\
\hline $7^{\text {th }}$ Week & 40 & 150 & 5 & 5 & 0 & Alive & $100 \%$ \\
\hline
\end{tabular}

\section{Antivenom of SSV(Thar \& costal Area) produced by oral Adjuent}

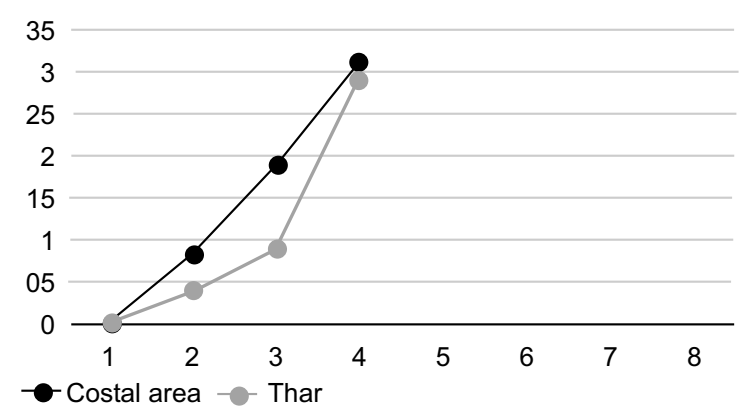

Fig. 4. Comparison of antivenom of Thar SSV with costal area SSV produced by oral adjuvant measured by ELISA.

significant ( $\mathrm{P}$ valve 0.058) means both the groups of SSV responds very well with mucosal immunization technique given by oral route.

Table 5 and 6 showed serum neutralization assay in vivo studies. Both groups of SSV venom produced sufficient antibodies when gave as oral adjuvant formulation and provided $100 \%$ protection after three doses of immunization.

\section{Conclusion}

There are no reference articles worldwide for use of anti-snake venom preparation, so the present study was carried out to develop an oral adjuvant formulation for delivery of snake venom to mucosal surface which have well defined lymphoid system for production of Anti snake venom immunoglobulin which also have the same potential as by the injectable path.

The majority of licensed vaccines was administered designed for subcutaneous or intramuscular injection for activation of systemic humoral immunity (e.g. antibody production) against specific antigen, with partial cellular immunity (e.g. T cell-mediated) and at mucosal surfaces only produce poor protection. Studied by Ramirez et al. (2017)

In contrast, in oral immunization the pathogen or toxin direct interact with mucosal surfaces induces successfully mucosal antibodies ( $\left.\mathrm{I}_{\mathrm{g}} \mathrm{A}\right)$ and cell-mediated immune responses which ultimately activate systemic antibody response $\left(\mathrm{I}_{\mathrm{g}} \mathrm{G}\right)$, Newsted et al. (2015)

Since, many decade several adjuvants have been used for several decades to develop stronger immune response with least adverse effects. These adjuvants induce better response to immune system than other formulation. Our findings strongly support the efficacy of oral adjuvantcarrier system for the effective induction of a specific immune response and targeted delivery system for production of anti-venom immunoglobulin described by Mehrabi et al. (2018)

More than 70 years adjuvants are use to design vaccines to improve the immune response to particular antigens, 
increase the duration of antibody response, and decrease the frequency of vaccination doses and the amount of antigen in each dose. Although water-in-oil emulsions are used for the long-term production of humoral immune response in poultry vaccines, as they are not suitable to be used in human vaccines, because they induce chronic inflammatory responce at the injection site stu died by Jafari et al. (2017) So, we used oil emulsion for oral route vaccination in equine animals Meenatchisun-daram et al. (2008) showed in his research the maximum titer of immunoglobulin $\mathrm{I}_{\mathrm{g}} \mathrm{G}$ against sawscale viper concentration varied in the ranged of $0.3-6.7$ $\mathrm{mg} / \mathrm{mL}$ of $\mathrm{I}_{\mathrm{g}} \mathrm{G}$ for Russell's viper venom, and 0.5-6.9 $\mathrm{mg} / \mathrm{mL}$ of $\mathrm{Ig}_{\mathrm{g}}$ for Saw-scaled viper venom throughout the immunization period. This study is comparable with our study which shows Immunoglobulin G titer is 0.6 $-2.9 \mathrm{ug} / \mathrm{uL}$ for Thar saw-scale viper and $0.8-3.1 \mathrm{ug} / \mathrm{uL}$ for costal area saw-scale viper.

Funding statement. This study was financially funded by Sindh Govt Health Department ADP scheme number 33 on going sero-biology, project establishment and research approval letter IRB-685/DUHS/ Approval/ 2016/184 from Dow University of Health Sciences.

Conflict of Interest. The authors declare no conflict of interest.

\section{References}

Beltrán-Beck, B., Romero, B., Sevilla, I.A., Barasona, J.A., Garrido, J.M., González-Barrio, D., Gortázar, C. 2014. Assessment of an oral Mycobacterium bovis $\mathrm{BCG}$ vaccine and an inactivated $M$. bovis preparation for wild boar in terms of adverse reactions, vaccine strain survival, and uptake by nontarget species. Clinical and Vaccine Immunology, 2: 12-20.

Berling, I., Isbister, G.K. 2015. Hematologic effects and complications of snake envenoming. Transfusion Medicine Reviews, 29: 82-89.

Bermúdez-Méndez, E., Fuglsang-Madsen, A., Føns, S., Lomonte, B., Gutiérrez, J.M., Laustsen, A.H. 2018. Innovative immunization strategies for antivenom development. Toxins, 10: 452.

Chambers, M.A., Aldwell, F., Williams, G.A., Palmer, S., Gowtage, S., Ashford, R., Nunez, A. 2017. The effect of oral vaccination with Mycobacterium bovis BCG on the development of tuberculosis in captive European badgers (Meles meles). Frontiers in Cellular and Infection Microbiology, 7: 6.
Cheng, Y., Wei, H., Sun, R., Tian, Z., Zheng, X. 2016. Rapid method for protein quantitation by Bradford assay after elimination of the interference of polysorbate 80. Analytical Biochemistry, 494: 37-39.

Hosseini, Z., Khosravi, M., Ghorbanpoor, M., Mayahi, M. 2017. Oral absorption of Mesobuthus eupeus scorpion venom in mice. Iranian Journal of Toxicology, 11: 15-19.

Jafari, M., Moghaddam, P.M., Taghizadeh, M., Masoudi, S., Bayat, Z. 2017. Comparative assessment of humoral immune responses of aluminum hydroxide and oil-emulsion adjuvants in Influenza $\left(\mathrm{H}_{9} \mathrm{~N}_{2}\right)$ and Newcastle inactive vaccines to chickens. Artificial Cells Nanomedicine and Biotechnology, 45: 8489.

León, G., Vargas, M., Segura, Á., Herrera, M., Villalta, M., Sánchez, A., Gutiérrez, J.M. 2018. Current technology for the industrial manufacture of snake antivenoms. Toxicon, 151: 63-73.

Meenatchisundaram, S., Parameswari, G., Michael, A., Ramalingam, S. 2008. Studies on pharmacological effects of Russell's viper and saw-scaled viper venom and its neutralization by chicken egg yolk antibodies. International Immunopharmacology, 8: $1067-1073$.

Mehrabi, M., Dounighi, N.M., Rezayat, S.S.M., Doroud, D., Amani, A., Khoobi, M., Pilehvar-Soltanahmadi, Y. 2018. Development and physico-chemical, toxicity and immunogenicity assess-ments of recombinant hepatitis B surface antigen ( $\mathrm{rHBsAg}$ ) entrapped in chitosan and mannosylated chitosan nano particles: as a novel vaccine delivery system and adjuvant. Artificial Cells Nanomedicine and Biotechnology, 46: 230-240.

Menon, J.C., Joseph, J.K., Whitaker, R.E. 2017. Venomous snake bite in India-Why do 50,000 Indians die every year. Journal of Association of Physicians of India, 65: 78-81.

Newsted, D., Fallahi, F., Golshani, A., Azizi, A. 2015. Advances and challenges in mucosal adjuvant technology. Vaccine, 33: 2399-2405.

Odedara, D.A. 2007. Snakebite: A Clinical Profile, Epidemiology, Prevelence, Blind Beliefs, Medical Treatment, Prophylaxis and Mortality in Saurashtra (Doctoral dissertation, Saurashtra University).

Park, M.E., Lee, S.Y., Kim, R.H., Ko, M.K., Park, J.N., Lee, K.N., Lee, J.S. 2016. Altered adjuvant of foot and mouth diseases vaccine improves immune response and protection from virus challenge. Trials 
in Vaccinology, 5: 97-104.

Parveen, G., Khan, M.F., Ali, H., Ibrahim, T., Shah, R. 2017. Determination of Lethal Dose (LD50) of venom of four different poisonous snakes found in Pakistan. Biochemistry and Molecular Biology Journal, 3: 18.

Ramirez, J.E.V., Sharpe, L.A., Peppas, N.A. 2017. Current state and challenges in developing oral vaccines. Advanced Drug Delivery Reviews, 114: 116-131.

Rastegar-Pouyani, N., Rastegar-Pouyani, E., Rhadi, F.A. 2016. Systematics of semi-venomous and venomous snakes of central and southern Iraq and molecular phylogeny of the genus Echis in Iraq, The Thesis (Ophidia: Viperidae).

Ratanabanangkoon, K., Tan, K.Y., Eursakun, S., Tan, C.H., Simsiriwong, P., Pamornsakda, T., Tan, N.H. 2016. A simple and novel strategy for the production of a pan-specific antiserum against elapid snakes of Asia. PLOS Neglected Tropical Diseases, 10: e0004565.
Rogalski, A., Soerensen, C., Op den Brouw, B., Lister, C., Dashevsky, D., Arbuckle, K., Wüster, W. 2017. Differential procoagulant effects of saw-scaled viper (Serpentes: Viperidae: Echis) snake venoms on human plasma and the narrow taxonomic ranges of antivenom efficacies. Toxicology Letters, 280: 159-170.

Shah, R.R., Brito, L.A., O'Hagan, D.T., Amiji, M.M. 2015. Emulsions as Vaccine Adjuvants. In: Proceeding Subunit Vaccine Delivery, pp. 59-76, Springer, New York, USA.

Valverde, J.M., Rodríguez, K., Herrera, M., Segura, Á., Vargas, M., Villalta, M., León, G. 2017. Comparison of the adjuvant activity of emulsions with different physico-chemical properties on the antibody response towards the venom of West African carpet viper (Echis ocellatus). Toxicon, 127: 106111.

World Health Organization (WHO). 2010. Guidelines for the Production, Control and Regulation of Snake Antivenom Immunoglobulins. Geneva: WHO, 134. 